\title{
Mar Menor lagoon (SE Spain) chlorophyll-a and turbidity estimation with Sentinel-2
}

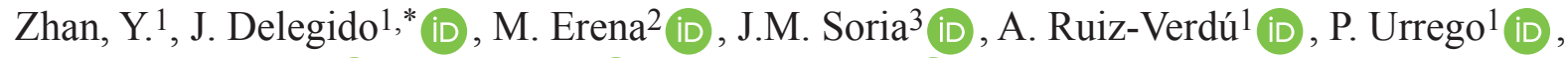 \\ X. Sòria-Perpinyà ${ }^{1}$ iD , E. Vicente ${ }^{3}$ iD and J. Moreno ${ }^{1}$ iD \\ ${ }^{1}$ Image Processing Laboratory, Universitat de València. C/ Catedrático José Beltrán Martínez, 2. 46980, Paterna, \\ València. \\ 2 GIS and Remote Sensing, IMIDA, C/ Mayor s/n. 30150 La Alberca. Murcia. \\ 3 Cavanilles Institute of Biodiversity and Evolutionary Biology (ICBiBE). Universitat de València. C/ Catedrático \\ José Beltrán Martínez, 2. 46980, Paterna, València. \\ * Corresponding author: jesus.delegido@uv.es
}

Received: 03/02/21 Accepted: $22 / 06 / 21$

\begin{abstract}
Mar Menor lagoon (SE Spain) chlorophyll- $a$ and turbidity estimation with Sentinel-2

Mar Menor is a Mediterranean Coastal lagoon with high environmental and social value, but has suffered important episodes of contamination in recent years due to heavy rains, sediment dragging and polluting substances mainly from agriculture as well as the entry of mining waste, causing an increase in eutrophication. Water quality variables such as chlorophyll- $a$ concentration $[\mathrm{Chl}-a]$ and turbidity, can be studied through its optical properties by remote sensing techniques. In this work, a methodology is proposed for monitoring [Chl-a] and the turbidity of the Mar Menor using Sentinel-2 images. For this purpose, an extensive database of both variables was used consisting of data taken on different dates between 2016 and 2019 at 12 points of Mar Menor. The images were atmospherically corrected using Case 2 Regional Coast Color Processor (C2RCC) version for turbid waters $(\mathrm{C} 2 \mathrm{X})$ to obtain the water surface reflectance. Then several arithmetic relations between database and reflectance bands used in the bibliography for [Chl-a] and turbidity were analyzed. Comparing the results of each one of these relations with the in situ data, decided that the best index for [Chl- $a$ ] estimation is the relation (R560 + R705)/ (R560 + R665) with an $\mathrm{RMSE}=2.6 \mathrm{mg} / \mathrm{m}^{3}$ and $\mathrm{NRMSE}=9.1 \%$ and for turbidity $\mathrm{R} 705 * \mathrm{R} 705 / \mathrm{R} 490$ with an $\mathrm{RMSE}=1.5 \mathrm{NTU}$ and a NRMSE $=10.9 \%$. Finally, by applying these relationships on different dates, thematic maps of [Chl- $a$ ] and turbidity of Mar Menor were obtained. One of these images was some days after September 2019 torrential rains, in which a considerable [Chl- $a$ ] and turbidity increase was observed.
\end{abstract}

Key words: Mar Menor, chlorophyll- $a$, turbidity, Sentinel-2, eutrophication, pollution

\section{RESUMEN}

\section{Estimación del contenido de clorofila-a y turbidez del Mar Menor con Sentinel 2}

El Mar Menor es un lago costero Mediterráneo con un alto valor medioambiental y social, pero que ha sufrido importantes episodios de contaminación en los últimos años a causa de fuertes lluvias, arrastre de sedimentos y sustancias contaminantes principalmente de la agricultura y la entrada de residuos mineros provocando un aumento de la eutrofización. La concentración de clorofila-a [Chl-a] y la turbidez son parámetros de calidad del agua que, por sus propiedades ópticas, pueden ser estudiadas con técnicas de teledetección. En este trabajo se propone una metodología para monitorizar el contenido en [Chl-a] y turbidez del Mar Menor usando imágenes de Sentinel-2. Para ello se ha utilizado una extensa base de datos, que cuenta con ambos parámetros, [Chl-a] y turbidez, medidos en diferentes fechas entre el año 2016 y 2019 en 12 puntos sobre el Mar Menor. Las imágenes fueron corregidas atmosféricamente con la versión para aguas turbias (C2X) del procesador Case 2 Regional Coast Colour Processor (C2RCC), para obtener los valores de reflectividad. A continuación, se analizaron las relaciones aritméticas entre las reflectividades de las bandas utilizadas en la bibliografia para el estudio de la [Chl-a] y la turbidez. Comparando cada una de esas relaciones con los datos in situ se obtuvo que el mejor índice para la [Chl-a] es la 
relación $(R 560+R 705) /(R 560+R 665)$ con un $R M S E=2.6 \mathrm{mg} / \mathrm{m}^{3}$ y un NRMSE $=9.1 \%$, para la turbidez $R 705 * R 705 / R 490$ con un RMSE $=1.5$ NTU y un NRMSE $=10.9 \%$. Finalmente se muestran mapas de [Chl-a] y turbidez del Mar Menor, aplicando estas relaciones en fechas distintas, una de ellas días después de las lluvias torrenciales de septiembre de 2019, donde se observa como la concentración de [Chl-a] y la turbidez aumentan considerablemente.

Palabras clave: Mar Menor, clorofila-a, turbidez, Sentinel 2, eutrofización

This is an open-access article distributed under the terms of the Creative Commons Attribution-NonCommercial 4.0 International (CC BY-NC 4.0) License.

\section{INTRODUCTION}

The water quality of lakes, lagoons, reservoirs and rivers is essential for human beings. Water has a high ecological value because is essential for life and it is the habitat for a large number of living organisms. The importance of water is also due to it is a source of energy. Although inland water masses only cover around $1 \%$ of Earth surface, it is the habitat of around $40 \%$ of fish species (FAO, 2020), and provides food and recreational resources that directly affect the life and economy of human population (Pérez-Ruzafa et al., 2019). Coastal lagoons are extremely complex and productive environments. They play a major role on carbon cycle by matter exchanging between the terrestrial and marine environment where its autotrophic organisms fix inorganic carbon using light as energy source, transforming inorganic carbon into organic carbon. In coastal lagoons, there are numerous physical and chemical processes that are sensitive to atmospheric phenomena, such as runoff incoming, marine intrusion or sediment incoming and resuspension (Bonilla \& Conde, 2000). The most prominent pollution process is eutrophication, characterized by the replacement of seaweed and low macroalgae biomass by large microalgae biomass as consequence of the excessive nutrient input. When eutrophication becomes chronic it causes hypoxic events, algal blooms that are often toxic, massive death of benthic seaweed and animals as well as changes in the patterns and structure of water bodies (Pérez-Ruzafa et al., 2019). The degree of eutrophication can be determined by measuring the chlorophyll- $a$ concentration $[\mathrm{Chl}-a]$ in the water, which is the essential photosynthetic pigment of phytoplankton (Gitelson et al., 2009).

Mar Menor is a hypersaline coastal lagoon
(Pérez-Ruzafa et al., 2005) that has been the center of attention for numerous controversies during the last years. Among them, the proliferation of the socalled green soup (De la Peña, 2020) due to the high [Chl- $a$ ] as a consequence of nutrients that reach the lagoon related with the practice of intensive agriculture, especially in the surroundings of the Cartagena countryside (Campillo et al., 2013). Added to this problem is the discharge of heavy metals and other contaminants from mining activity. that aggravates the situation (Calvo, 2020) affecting the lagoon sediments, which present a high concentration of metals and toxicity, mainly at south-western part of the lagoon, determining the presence of heavy metals in benthic organisms (Marín-Guirao et al., 2005). Another problem of the lagoon is the loss of depth due to the increase in frequency of extreme rains that have led a greater sediment transportation (Marín-Guirao et al., 2005). All of these problems that have occurred on Mar Menor for years have disturbed its old equilibrium (Álvarez et al., 2016) of low productivity and clear waters typical of an oligotrophic lagoon (Erena et al., 2017), changing the phytoplankton composition (Soria et al., 2020).

The great interest in water quality studies and the development of remote sensing techniques during the last decades have fostered improved methods that allow the temporary study of large aquatic surfaces, such as Mar Menor, using satellite images (Matthews, 2011).

In studies of inland and marine waters by remote sensing, the quality of the water body can be determined by its optical properties (Ogashawara et al., 2017), that have spatial and temporal variations related with physical qualities and biological water composition (Soomets et al., 2020). The optical properties of pure water are modified 
by dissolved and suspended substances (Ogashawara et al., 2017) that can be correlated with information obtained by remote sensing (Han et al., 2016). Among the physical properties that can be studied by remote sensing, the most notable are turbidity, defined as the lack of transparency of a liquid due to the presence of suspended particles and Chl-a, with a characteristic absorption spectrum of visible light (Soomets et al., 2020), which is used as an index of phytoplankton biomass.

In recent years, many satellite missions for Earth observation purposes have been designed. In this respect, the Copernicus program is an initiative between the European Commission and the European Space Agency (ESA) that includes the development of several satellite missions that aim to contribute to protection of the environment, health, agriculture and security of their citizens (Jutz \& Milagro-Pérez, 2020). The program offers quality data and services for free. The Sentinel-2 mission stands out within the Copernicus program, which consists of 2 identical satellites A and

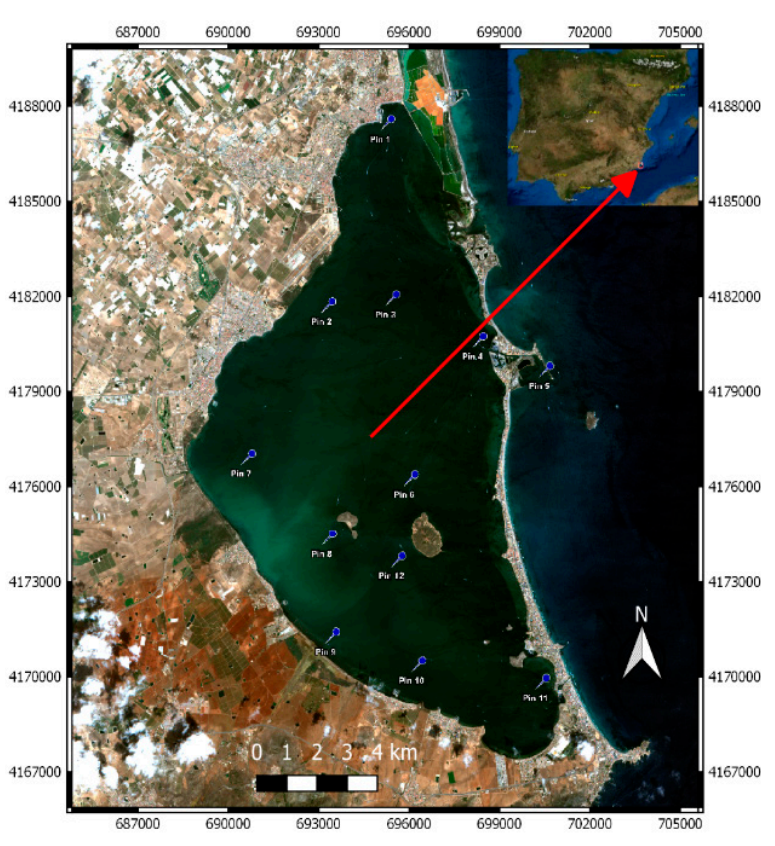

Figure 1. RGB composition of Mar Menor made with a Sentinel-2 image, showing the pins (markers) for sampling points. Composición $R G B$ de del Mar Menor realizado con una imagen de Sentinel 2 mostrando los pines de los puntos de muestreo.
B, launched in 2015 and 2017 respectively. With the combination of the two satellites, coverage is attained every 5 days at the equator, reaching revisits every 2-3 days at mid-latitudes (ESA, 2020). Both satellites have on board the Multispectral Instrument (MSI) sensor with 13 spectral bands ranging from visible to near infrared (Drusch et al., 2012) between 443 and $2190 \mathrm{~nm}$, with spatial resolution of 10, 20 and $60 \mathrm{~m}$ (ESA, 2020).

Sentinel-2 provides terrestrial optical images, available level $1 \mathrm{C}$ products, which are radiometrically and geometrically corrected. In addition, ESA also provides level $2 \mathrm{~A}$ products, whose images are corrected for the disturbance introduced by the atmosphere, a process known as atmospheric correction.

The objective of this work is to develop the best methodology for monitoring the [Chl-a] content and turbidity of Mar Menor with Sentinel-2 images, using field data obtained between 2016 to 2019 . This methodology should serve to establish environmental monitoring of the lagoon in efficient way, without need of continuous in situ sampling.

\section{MATERIALS AND METHODS}

\section{Study area and in situ data}

Mar Menor is a hypersaline coastal lagoon located in the province of Murcia (SE Spain) and the surroundings, islands and wetlands, comprise a designated area of 14527 ha, protected under a combination of international, European and Spanish environmental policies. It is noted as a Special Protected Area (SPA) under the EU Birds Directive (79/409/EEC), supporting important numbers of migrant and aquatic birds. Some areas of Mar Menor were also recognized under the Ramsar Convention with the number 706 at October 1994, being a Site of Community Importance (SCI) under the EU Habitats Directive (92/43/ EEC) and Special Protected Area of Mediterranean Interest (SPAMI) within the Barcelona Convention for the Protection of the Mediterranean Sea against Pollution since October 2001. The protection status based on the "Natura 2000" network established by Habitats EU Directive (92/43/EEC) includes three categories at Mar Menor area: priority and non-priority Habitats, 
depending on if they are in danger of disappearance or not, and zones without this status. Mar Menor coastal lagoon is also regulated by local laws. This region has a semi-arid climate with a mean annual temperature of $18{ }^{\circ} \mathrm{C}$, an average annual precipitation of $300 \mathrm{~mm}$, and a potential evapotranspiration of $1275 \mathrm{~mm} / \mathrm{yr}$ (Sanchez et al., 1989). The Mar Menor lagoon (Fig. 1) has a surface of $135 \mathrm{~km}^{2}$ and a volume of $593 \mathrm{hm}^{3}$, with mean depth of $4.5 \mathrm{~m}$ and maximum depth $<6.5 \mathrm{~m}$. Renewal time rate ranges from 0.66 to 1.2 year (Pérez-Ruzafa et al. 2005). The lagoon is one of the largest in the Mediterranean basin (Perez-Ruzafa et al., 2011; Perez-Ruzafa et al., 2013) and the largest along the Spanish Mediterranean coast. It is separated from the open sea by a 22-km-long sand bar (La Manga), although one natural connection with sea and two artificial canals allows some water renewal (water velocity in the lagoon is lower than $0.03 \mathrm{~m} / \mathrm{s}$ ) (Garcia-Oliva et al., 2018).

The database used in this work was obtained through measurements acquired by the IMIDA (Murcian Institute for Agricultural and Food Research and Development) from August 2, 2016 to October 15, 2019 with a frequency between 4 and 5 times a month, taking measurements at 12 points of Mar Menor. Overall, the used database has an average of 152 field campaigns on different dates for each sampling point, with a total of 1827 made measurements. The instrument used to carry out water quality measurements was a Sea Bird Electronics SBE-19 equipped with three fluorimeters to measure, among other variables, [Chl-a] (in $\mathrm{mg} / \mathrm{m}^{3}$ ) and turbidity (measured in Nephelometric Units or Nephelometric Turbidity Units, NTU) (Erena et al., 2019). The measurements were always carried out at the same points with fixed coordinates and distributed throughout Mar Menor. Figure 1 shows the sampling points (pins) with their numbering. Point 5 is located outside the Mar Menor, specifically at the port and the rest are located within the lagoon. All points are more than 200 meters away from the shore, which serves to minimize the adjacency effect on satellite images once are analyzed. This database has measurements at each point at different depths, including between 0-1 $\mathrm{m}, 1-2 \mathrm{~m}$, 2-3 m, 3-4 m and 5-6 m. In our study, we chose [Chl- $a$ ] and turbidity measurements obtained at depths between 0 and 1 meters, since they are the ones that best correlate with remote sensing data.

\section{Sentinel-2 image processing}

The main characteristics of Sentinel-2 mission are given in table 1, indicating its band configuration and spatial resolution. Sentinel-2 images were downloaded from the web address https:// scihub.copernicus.eu from Copernicus program, and https://earthexplorer.usgs.gov from United States Geolgical Survey (USGS).

Cloud-free images over Mar Menor were selected from the database to synchronize with sampling dates. To increase the number of available images, those with some clouds but without covering over the sampling points were also used. In total, 14 dates were downloaded following the previously established criterion, with 158 coincident pixels with [Chl- $a$ ] points and 157 coincident pixels with measured turbidity points, for a total of 315 data from the in situ database. The dates of selected images are given in table 2. For image processing, we use the SNAP program (Sentinel Application Platform), which is a free software developed by ESA, specifically for image processing. Used images belong to level $1 \mathrm{C}$, georeferenced but without atmospheric correction that are ortho-images of $100 \times 100 \mathrm{~km}$ in the UTM/ WGS84 projection. All bands were resampled at $20 \mathrm{~m}$ and the images were cut out to select the area corresponding to Mar Menor. Next, we proceeded to perform the atmospheric correction of each image. For this process, we used an atmospheric correction method incorporated into SNAP program: Case 2 Regional Coast Color Processor (C2RCC), based on a multilayered method per pixel of an artificial neural network (Warren et al., 2019) and has two versions: C2RCC for oceanic waters and $\mathrm{C} 2 \mathrm{X}$ for turbid waters (Hieronymi et al., 2016). Version C2X is more satisfactory to mesotrophic to hypertrophic waters (PereiraSandoval et al., 2019), and is therefore more suitable for Mar Menor study due to its trophic state, maintaining the predetermined variables. This process delivers a new product, level $2 \mathrm{~A}$, with a folder containing a series of bands that provide water leaving reflectance and a folder with two automatic products: [Chl- $a$ ] and total suspended 
solids, which are developed through neural networks (Brockmann et al., 2016).

\section{Algorithms determination}

The reflectance spectra from water surface were extracted in 3x3 pixel windows (Kutser, 2012), centered in the pin corresponding to each sampled point, for a total of 9 spectra per point. This was done to reduce noise because if only the center pixel values were extracted, there could be anomalous values as the $\mathrm{C} 2 \mathrm{X}$ processor sometimes provides erroneous punctual results.
For validation $[\mathrm{Chl}-a]$ automatic product, the [Chl- $a$ ] values of the 9 pixels were extracted to select only those pixels with values that are within Mar Menor [Chl- $a$ ] range. Pixels with [Chl- $a$ ] values under $0.001 \mathrm{mg} / \mathrm{m}^{3}$ were eliminated, since they are considered erroneous as the values of the lagoon are always higher than this value. Then, the $[\mathrm{Chl}-a]$ automatic product medians and standard deviations of the remaining pixels were calculated for each measurement point. Furthermore, values above the median plus the standard deviation and those below the median minus the deviation were also eliminated (Pereira-Sandoval et

Table 1. Characteristics of Sentinel-2 spectral bands. Características de las bandas espectrales de Sentinel 2.

\begin{tabular}{llll}
\hline $\begin{array}{l}\text { Band Number } \\
\text { (Spatial Resolution) }\end{array}$ & Band Description & $\begin{array}{l}\text { Central } \\
\text { Wavelength (nm) }\end{array}$ & $\begin{array}{l}\text { Bandwith } \\
(\mathbf{n m})\end{array}$ \\
\hline Band 1 (60 m) & Deep blue (Coastal aerosol) & 443 & 20 \\
Band 2 (10 m) & Blue & 490 & 65 \\
Band 3 $(10 \mathrm{~m})$ & Green & 560 & 35 \\
Band 4 (10 m) & Red & 665 & 30 \\
Band 5 (20 m) & Red-edge & 705 & 15 \\
Band 6 (20 m) & Red-edge & 740 & 15 \\
Band 7 (20 m) & Red-edge & 783 & 20 \\
Band 8 (10 m) & Near infrared (NIR) & 842 & 115 \\
Band 8A (20 m) & Near infrared narrow (NIRn) & 865 & 20 \\
Band 9 (60 m) & Water vapour & 945 & 20 \\
Band 10 (60 m) & Shortwave infrared / Cirrus & 1375 & 30 \\
Band 11 (20 m) & Shortwave infrared 1 (SWIR1) & 1610 & 90 \\
Band 12 (20 m) & Shortwave infrared 2 (SWIR2) & 2190 & 180 \\
\hline
\end{tabular}

Table 2. Dates of Sentinel-2 images selected with the established criterion. Fechas de las imagines de Sentinel 2 seleccionadas con los criterios establecidos.

\begin{tabular}{llll}
\hline $28 / 10 / 2016$ & $20 / 06 / 2018$ & $07 / 11 / 2018$ & $14 / 08 / 2019$ \\
$30 / 06 / 2017$ & $10 / 07 / 2018$ & $12 / 03 / 2019$ & $18 / 09 / 2019$ \\
$20 / 02 / 2018$ & $29 / 08 / 2018$ & $25 / 06 / 2019$ & $03 / 10 / 2019$ \\
$07 / 03 / 2018$ & $03 / 10 / 2018$ & & \\
\hline
\end{tabular}


al., 2019; Müller et al., 2015). Finally, we calculate the mean and standard deviation of each pin of [Chl- $a$ ] automatic product with the remaining values. These were the values compared with the field data to validate this product.

Regarding the reflectance data, the final spectrum of the pin was calculated by averaging the reflectance of the selected pixels in the $3 \times 3$ window (Kutser, 2012). Then, the mean [Chl-a] and turbidity values measured in field were assigned to each point, generating a database that allows the study of different combinations of bands. The method used was to apply the mathematical combination of a reflectance band from previous works, both [Chl-a] and turbidity, to find the best correlation with these variables. The range of reflectance present in the mathematical combinations is convoluted to the Sentinel-2 bands and shown in tables 3 and 4 for [Chl-a], and table 5 for turbidity. Finally, those combinations of bands that obtained the best linear correlation with the variable under study ([Chl- $a]$ or turbidity) were selected according to the coefficient of determination $\mathrm{R}^{2}$ and the root mean square error RMSE.

\section{RESULTS AND DISCUSSION}

\section{Retrieval algorithms for [Chl-a]}

We used a total amount of 158 in situ measurements, with $3.57 \mathrm{mg} / \mathrm{m}^{3}$ average and $6.12 \mathrm{mg} / \mathrm{m}^{3}$ standard deviation, ranging between 0.09 $27.99 \mathrm{mg} / \mathrm{m}^{3}$.

The best combinations of reflectance bands from Sentinel-2 related with in situ [Chl-a] are given in table 6 , including its coefficients of determination, the lineal regression equation, and its RMSE and NRMSE. Graphs of relationships are shown in figure 2 . The combination with a better correlation with $\mathrm{R}^{2}=0.82$ is obtained with the formula:

$$
[\mathrm{Chl}-a]\left(\mathrm{mg} / \mathrm{m}^{3}\right)=\frac{124.94(\mathrm{R} 560+\mathrm{R} 705)}{(\mathrm{R} 560+\mathrm{R} 665)}-115.35(1)
$$

In this combination, the green band centered at $560 \mathrm{~nm}$ is the region less affected by pigment absorption (Delegido et al., 2014). The $665 \mathrm{~nm}$ band, corresponding to red, where $[\mathrm{Chl}-a]$ has a secondary absorption peak (Elosegi et al., 2009) and $705 \mathrm{~nm}$ band that corresponds to the region where the influence of [Chl- $a]$ is minimum and is mainly related to phytoplankton backscattering (Delegido et al., 2014), although water continues to absorb in this band. In the second-best correlation, the combination (R705-R740)/(R665$\mathrm{R} 740)$ with $\mathrm{R}^{2}=0.808$, the reflectances to 705 $\mathrm{nm}$ and $665 \mathrm{~nm}$ bands are also present, as with the third combination (R705-R783)/(R665-R783) with $\mathrm{R}^{2}=0.807$. That is, the reflectances of the $705 \mathrm{~nm}$ and $665 \mathrm{~nm}$ bands are present in all combinations with the best correlations. If the principle of parsimony states that in a set of explanatory variables that are part of the studied model, the smallest and simplest possible combination must be chosen (Delegido et al., 2014), it would also be acceptable, for its simplicity, to use the R705/ $\mathrm{R} 665$ index with $\mathrm{R}^{2}=0.766$ with the equation:

$$
[\mathrm{Chl}-a]\left(\mathrm{mg} / \mathrm{m}^{3}\right)=32.448\left(\frac{\mathrm{R} 705}{\mathrm{R} 665}\right)-21.408
$$

Table 3. Mathematical combinations most used by different authors for remote sensing [Chl- $a$ ] determination, where $\mathrm{Ri}$ is the reflectance for i-centered spectral band (nm). Combinaciones matemáticas más utilizadas por los distintos autores en la determinación de [Chl-a] por teledetección, donde Ri es la reflectancia en el banda espectral centrada-i ( $\mathrm{nm}$.

\begin{tabular}{ll}
\hline Source & Combination \\
\hline Cairo et al., 2019 & R740/R560 \\
Erena et al. 2019 & (R560-R490)/(R560+R490) \\
Gitelson et al., 2009 & R740*((1/R665)-(1/R705)) \\
Moses et al., 2009 & R740/R665 \\
Koponen et al., 2007 & R705/R665 \\
Candiani et al., 2005 & R560/R665 \\
Giardino et al., 2005 & (R443-R783)/(R490-R705) \\
Giardino et al., 2005 & R490 \\
Strömbeck et al., 2004 & R560/R705 \\
Floricioiu et al., 2003 & R665/R560 \\
Floricioiu et al., 2003 & R665/R490 + R560/R490 \\
Koponen et al., 2002 & (R705-R783)/(R665-R783) \\
Flink et al., 2001 & R560 \\
Flink et al., 2001 & R705/R665+ R665/R560 \\
Härmä et al., 2001 & (R705-R740)/(R665-R740) \\
\hline
\end{tabular}


Table 4. Mathematical spectral band reflectance combinations used in Delegido et al. (2014). Combinaciones matemáticas de la reflectancia de las bandas espectrales utilizadas en Delegido et al. (2014).

\begin{tabular}{llll}
\hline $\log (\mathrm{R} 705 / \mathrm{R} 665)$ & $(1 / \mathrm{R} 490)-(1 / \mathrm{R} 705)$ & $(\mathrm{R} 490+\mathrm{R} 705) / \mathrm{R} 490$ & $(\mathrm{R} 705+\mathrm{R} 783) /(\mathrm{R} 490+\mathrm{R} 783)$ \\
$\mathrm{R} 665 / \mathrm{R} 740$ & $(1 / \mathrm{R} 560)-(1 / \mathrm{R} 705)$ & $\mathrm{R} 705 * \mathrm{R} 705 / \mathrm{R} 490$ & $(\mathrm{R} 705+\mathrm{R} 783) /(\mathrm{R} 560+\mathrm{R} 783)$ \\
$\log (\mathrm{R} 443 / \mathrm{R} 560)$ & $(1 / \mathrm{R} 665)-(1 / \mathrm{R} 705)$ & $\mathrm{R} 705 * \mathrm{R} 705 / \mathrm{R} 665$ & $(\mathrm{R} 490-\mathrm{R} 783) /(\mathrm{R} 560+\mathrm{R} 490)$ \\
$\log (\mathrm{R} 490 / \mathrm{R} 560)$ & $(\mathrm{R} 490-\mathrm{R} 705) / \mathrm{R} 490$ & $\mathrm{R} 705 /(\mathrm{R} 490 * \mathrm{R} 490)$ & $(\mathrm{R} 560-\mathrm{R} 783) /(\mathrm{R} 560+\mathrm{R} 665)$ \\
$\mathrm{R} 705 / \mathrm{R} 490$ & $(\mathrm{R} 590-\mathrm{R} 705) / \mathrm{R} 665$ & $\mathrm{R} 783 /(\mathrm{R} 490 * \mathrm{R} 665)$ & $(\mathrm{R} 490-\mathrm{R} 705) /(\mathrm{R} 490+\mathrm{R} 705)$ \\
$\mathrm{R} 705 / \mathrm{R} 560$ & $(\mathrm{R} 665-\mathrm{R} 705) / \mathrm{R} 665$ & $(\mathrm{R} 560+\mathrm{R} 705) /(\mathrm{R} 560+\mathrm{R} 665)$ & $(\mathrm{R} 560-\mathrm{R} 705) /(\mathrm{R} 560+\mathrm{R} 705)$ \\
$(\mathrm{R} 665-\mathrm{R} 705) /(\mathrm{R} 665+\mathrm{R} 705)$ & & & \\
\hline
\end{tabular}

The best correlation for retrieval $[\mathrm{Chl}-a]$ has been obtained with a four band model tested by Delegido et al. (2014), (R560 + R705) / (R560 + R665). The good correlation coefficient and the low NRMSE $=9.1 \%$, show that the algorithm used delivers very good matching results for the studied water body. The $p$-value is less than 0.001 in all cases.

Regarding studies carried out specifically at Mar Menor, using Landsat satellite images Erena et al. (2019) obtained the best correlation index with the green and red bands

$$
\frac{R(\text { green })-R(\text { blue })}{R(\text { green })+R(\text { blue })}
$$

obtaining an $\mathrm{R}^{2}=0.887$, but the index tested with data of our study obtain a $\mathrm{R}^{2}=0.298$.

Our results with the four band model are also similar to those obtained by Sòria-Perpinyà et al. (2019) for Albufera of València, a coastal lagoon to the Northeast of Mar Menor. Using the TDBO, triband model of Dall'Olmo et al. (2003),

$$
T D B O=R(740) x\left(\frac{1}{R(665)}-\frac{1}{R(705)}\right)
$$

they obtained a mean absolute error of $9.6 \%$ for a wide $[\mathrm{Chl}-a]$ range $4.5-209 \mathrm{mg} / \mathrm{m}^{3}$. This triband model was also tested for this study, getting one of the five best correlations with NRMSE of $10.3 \%$.

If we chose the smallest and simplest possible combination, it is acceptable to use, for [Chl- $a$ ] estimations, the ratio $\mathrm{R} 705 / \mathrm{R} 665$ with $\mathrm{R}^{2}=0.77$,
Table 5. Used indices for the turbidity study. Indices usados para el estudio de la turbidez.

\begin{tabular}{ll}
\hline Source & Combination \\
\hline Erena et al., 2019 & (R560-R490)/(R560+R490) \\
Yuan et al., 2019 & R783/R490 \\
Caballero et al., 2018 & $\mathrm{R} 665$ \\
Caballero et al., 2018 & $\mathrm{R} 865$ \\
Hou et al., 2017 & $(\mathrm{R} 560+\mathrm{R} 705) /(\mathrm{R} 560+\mathrm{R} 665)$ \\
Hou et al., 2017 & $\mathrm{R} 665 / \mathrm{R} 560$ \\
Petus et al., 2010 & $\mathrm{R} 490$ \\
Doxaran et al., 2009 & $\mathrm{R} 865 / \mathrm{R} 560$ \\
Doxaran et al., 2009 & $\mathrm{R} 490 / \mathrm{R} 443$ \\
Koponen et al., 2007 & $\mathrm{R} 705 /(\mathrm{R} 560+\mathrm{R} 665)$ \\
Doxaran et al., 2002 & $\mathrm{R} 560 / \mathrm{R} 443$ \\
Kallio et al., 2001 & $\mathrm{R} 705$ \\
Härmä et al., 2001 & $\mathrm{R} 705-\mathrm{R} 740$ \\
Härmä et al., 2001 & (R443-R665)/(R560-R665) \\
Gitelson et al., 1993 & (R560-R490)/(R560+R490) \\
Lathrop \& Lillesand,1989 & $\mathrm{R} 490 /(\mathrm{R} 443+\mathrm{R} 560)$ \\
This study & $\mathrm{R} 783$ \\
This study & $\mathrm{R} 865 / \mathrm{R} 443$ \\
This study & $\mathrm{R} 865 / \mathrm{R} 490$ \\
This study & $\mathrm{R} 865 * \mathrm{R} 783 / \mathrm{R} 490$ \\
This study & $\mathrm{R} 783 * \mathrm{R} 705 / \mathrm{R} 490$ \\
\hline & $\mathrm{R} 705 * \mathrm{R} 705 / \mathrm{R} 490$ \\
This study & $(\mathrm{R} 783 / \mathrm{R} 490)+(\mathrm{R} 665 / \mathrm{R} 560)$ \\
\hline
\end{tabular}



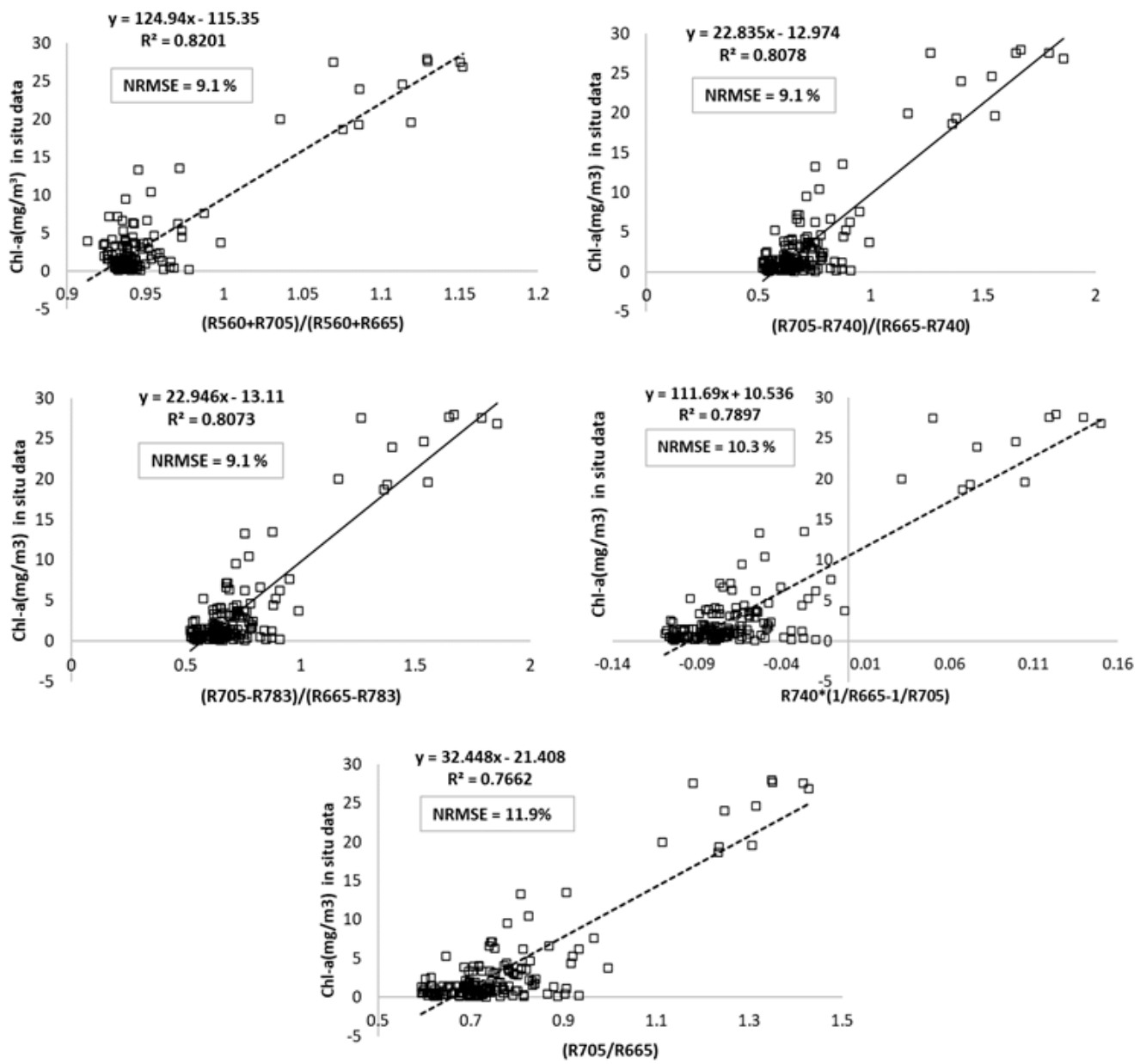

Figure 2. Relationships between [Chl- $a$ ] field data and the best Sentinel-2 spectral band combinations. Relaciones entre la [Chl-a] del dato de campo y las mejores combinaciones de bandas.

Table 6. Better arithmetic combinations and statistics results, where 0rdinates (y) are [Chl-a] and Abscissas (x) are the spectral index (combination). Mejores combinaciones aritméticas y sus estadísticas, donde la ordenada (y) es [Chl-a] y la abscisa (x) es el índice espectral (combinación).

\begin{tabular}{ccccc}
\hline Combination & $\mathbf{R}^{2}$ & Equation & RMSE $\left(\mathbf{m g} / \mathbf{m}^{3}\right)$ & NRMSE $(\%)$ \\
\hline $\mathbf{( R 5 6 0 + R 7 0 5 ) / ( R 5 6 0 + R 6 6 5 )}$ & 0.820 & $\mathrm{y}=124.94 \mathrm{x}-115.35$ & 2.6 & 9.1 \\
$(\mathbf{R 7 0 5}-\mathbf{R 7 4 0 )} /(\mathbf{R 6 6 5}-\mathbf{R 7 4 0 )}$ & 0.808 & $\mathrm{y}=22.835 \mathrm{x}-12.974$ & 2.7 & 9.1 \\
$(\mathbf{R 7 0 5}-\mathbf{R 7 8 3 )} /(\mathbf{R 6 6 5}-\mathbf{R 7 8 3})$ & 0.807 & $\mathrm{y}=22.946 \mathrm{x}-13.11$ & 2.7 & 9.1 \\
$\mathbf{R 7 4 0 * ( 1 / R 6 6 5 - 1 / R 7 0 5 )}$ & 0.790 & $\mathrm{y}=111.69 \mathrm{x}+10.536$ & 2.8 & 10.3 \\
$\mathbf{R 7 0 5 / \mathbf { R 6 6 5 }}$ & 0.766 & $\mathrm{y}=32.448 \mathrm{x}-21.408$ & 3.0 & 11.9 \\
\hline
\end{tabular}




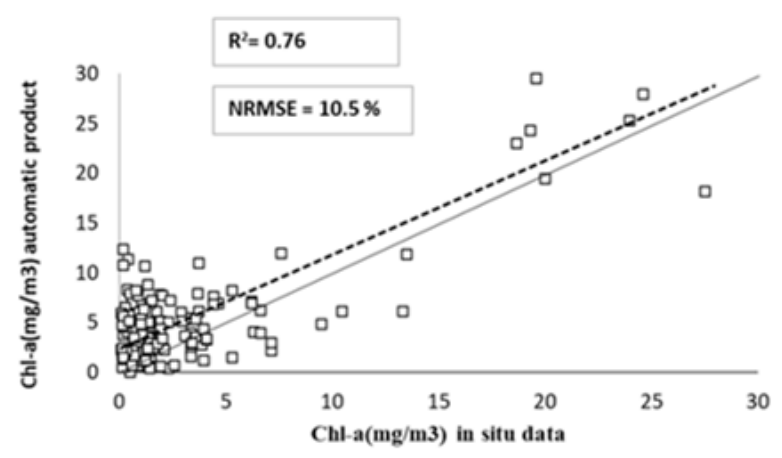

Figure 3. Validation relationship between $[\mathrm{Chl}-a]$ of Sentinel-2 automatic product with field [Chl- $a$ ] measurements, where the line represents the 1: 1 line and the line dashes the fit. Validación de la relación entre la [Chl-a] del producto automático de Sentinel-2 con las medidas de campo de [Chl-a], donde la linea representa la recta 1:1 y la línea guion el ajuste.

$\mathrm{RMSE}=3.0 \mathrm{mg} / \mathrm{m}^{3}$ and $\mathrm{a}$ NRME $=11.9 \%$ for a range between 0.11 and $24.89 \mathrm{mg} / \mathrm{m}^{3}$, also obtained with good results in several studies utilizing Sentinel-2 data. One example is the study of Lins et al. (2017) at an estuarine lagoon, where they obtained a $\mathrm{R}^{2}=0.78$ and $\mathrm{RMSE}=10.44 \mathrm{mg} / \mathrm{m}^{3}$ with a [Chl- $a$ ] range of $0.97-117.24 \mathrm{mg} / \mathrm{m}^{3}$. Another example is the study of Chen et al. (2017) at Lake Huron, where they obtained $\mathrm{R}^{2}=0.49$ and a RMSE $=9.97$ with a $[\mathrm{Chl}-a]$ range of $1.62-51.68 \mathrm{mg} / \mathrm{m}^{3}$.

\section{C2X [Chl-a] automatic product vs [Chl-a] in situ data}

On the other hand, as we have mentioned before, when doing the atmospheric correction with C2X, the SNAP software provides several automatic products, among them [Chl- $a$ ]. In order to validate this product with field data, in figure 3 we show the relationship between [Chl-a] automatic product obtained with C2X and $[\mathrm{Chl}-a]$ in situ measurements. This allows us to know if this automatic product provides better results than our calculated indices. For this, we calculate its NRMSE $=10.48 \%$ and RMSE obtaining a value of $3.9 \mathrm{mg} / \mathrm{m}^{3}$, values greater than obtained with the 5 best indices. Therefore, the calibrated arithmetic combinations are better methods to measure Mar Menor
[Chl- $a]$ than the automatic product given by SNAP. The automatic product works well enough since it has been calibrated with a wide database valid for a wide range of water types, while the indices obtained have been specifically calibrated with field data from Mar Menor.

\section{Retrieval algorithms for turbidity}

We used a total amount of 157 in situ measurements, with 2.25 NTU average and 2.82 NTU standard deviation, ranging between $0.1-15.89$ NTU.

The best correlations between the measured turbidity in the field and the different indices obtained from Sentinel-2 reflectances are given in table 7 and shown in figure 4 . We observe that the highest correlation is obtained with the ratio R705*R705/ $\mathrm{R} 490$ with $\mathrm{R}^{2}=0.7303$, using the equation:

$$
\text { Turbidity }(\mathrm{NTU})=194.79\left(\mathrm{R} 705 * \frac{\mathrm{R} 705}{\mathrm{R} 490}\right)+0.9061(3)
$$

In this equation, the reflectance of the band $705 \mathrm{~nm}$ is present, which is mainly related to the scattering in the near infrared caused by the suspended particles and the band $490 \mathrm{~nm}$ that corresponds to the blue band, where the water reflects the most and its reflectance decreases with the presence of suspended solids, affecting turbidity (Sebastiá-Frasquet et al., 2019).

The second-best correlation is $\mathrm{R} 783 * \mathrm{R} 705 /$ $\mathrm{R} 490$ with an $\mathrm{R}^{2}=0.7013$. In this combination, we consider the band $783 \mathrm{~nm}$, which is sensitive to high concentrations of suspended particles, to be able to overcome the strong water absorption in this spectral region.

The third best correlation (R783-R865)/R490 with $\mathrm{R}^{2}=0.673$ uses the reflectances of bands $783 \mathrm{~nm}$ and $490 \mathrm{~nm}$, and the reflectance of the band $865 \mathrm{~nm}$ is added.

The fourth best correlation R783/R490 with an $\mathrm{R}^{2}=0.666$ is the simplest relation that has been obtained.

The fifth best correlation is R $865 * \mathrm{R} 783 / \mathrm{R} 490$ also uses the same bands as the third combination. The $p$-value is less than 0.001 in all cases.

The calibrated equations allow to obtain maps of turbidity at the whole Mar Menor, selecting in this case for Mar Menor the equation 3 that obtains the best statistics with a combination of only two bands. 

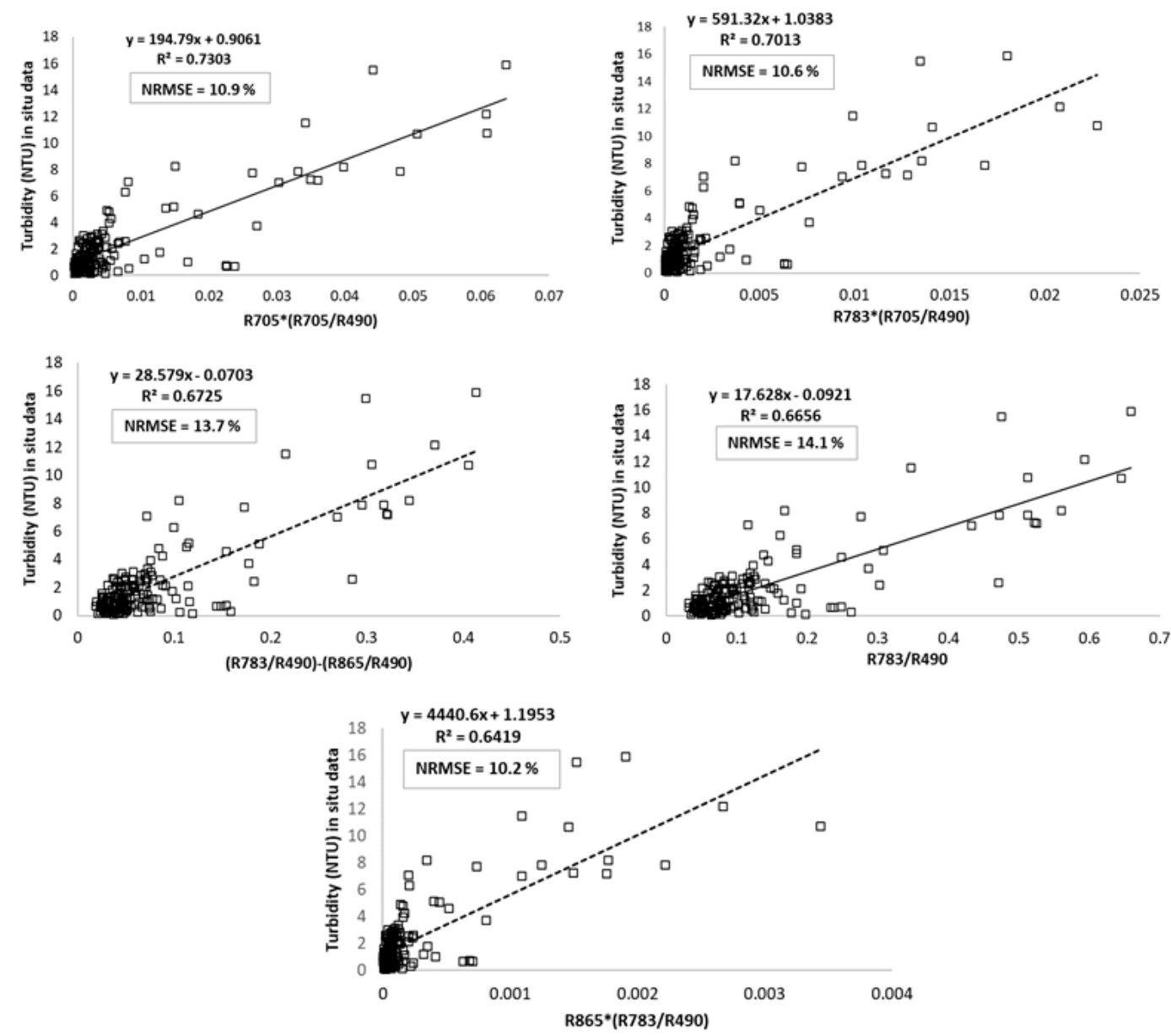

Figure 4. Relationships between turbidity field data and best Sentinel-2 spectral band combinations. Relación entre la turbidez del dato de campo y las mejores combinaciones de las bandas de Sentinel 2.

Table 7. Better arithmetic combinations and statistics results, where 0rdinates (y) are turbidity and Abscissas (x) are the spectral index (combination). Mejores combinaciones aritméticas obtenidas y sus estadísticas, donde la ordenada (y) es la turbidez y la abscisa ( $x$ ) es el indice espectral (combinación).

\begin{tabular}{ccccc}
\hline Combination & $\mathbf{R}^{2}$ & Equation & RMSE (NTU) & NRMSE(\%) \\
\hline $\mathbf{R 7 0 5 * R 7 0 5 / R 4 9 0}$ & 0.730 & $\mathrm{y}=194.79 \mathrm{x}+0.9061$ & 1.5 & 10.9 \\
$\mathbf{R 7 8 3 * \mathbf { R 7 0 5 } / \mathbf { R } 4 9 0}$ & 0.701 & $\mathrm{y}=591.32 \mathrm{x}+1.0383$ & 1.5 & 10.6 \\
$\mathbf{( R 7 8 3 - \mathbf { R 8 6 5 } ) / \mathbf { R } 4 9 0}$ & 0.673 & $\mathrm{y}=28.579 \mathrm{x}-0.0703$ & 1.6 & 13.7 \\
$\mathbf{R} 783 / \mathbf{R} 490$ & 0.666 & $\mathrm{y}=17.628 \mathrm{x}-0.0921$ & 1.6 & 14.1 \\
$\mathbf{R 8 6 5} * \mathbf{R 7 8 3} / \mathbf{R} 490$ & 0.642 & $\mathrm{y}=4440.6 \mathrm{x}+1.1953$ & 1.7 & 10.2 \\
\hline
\end{tabular}



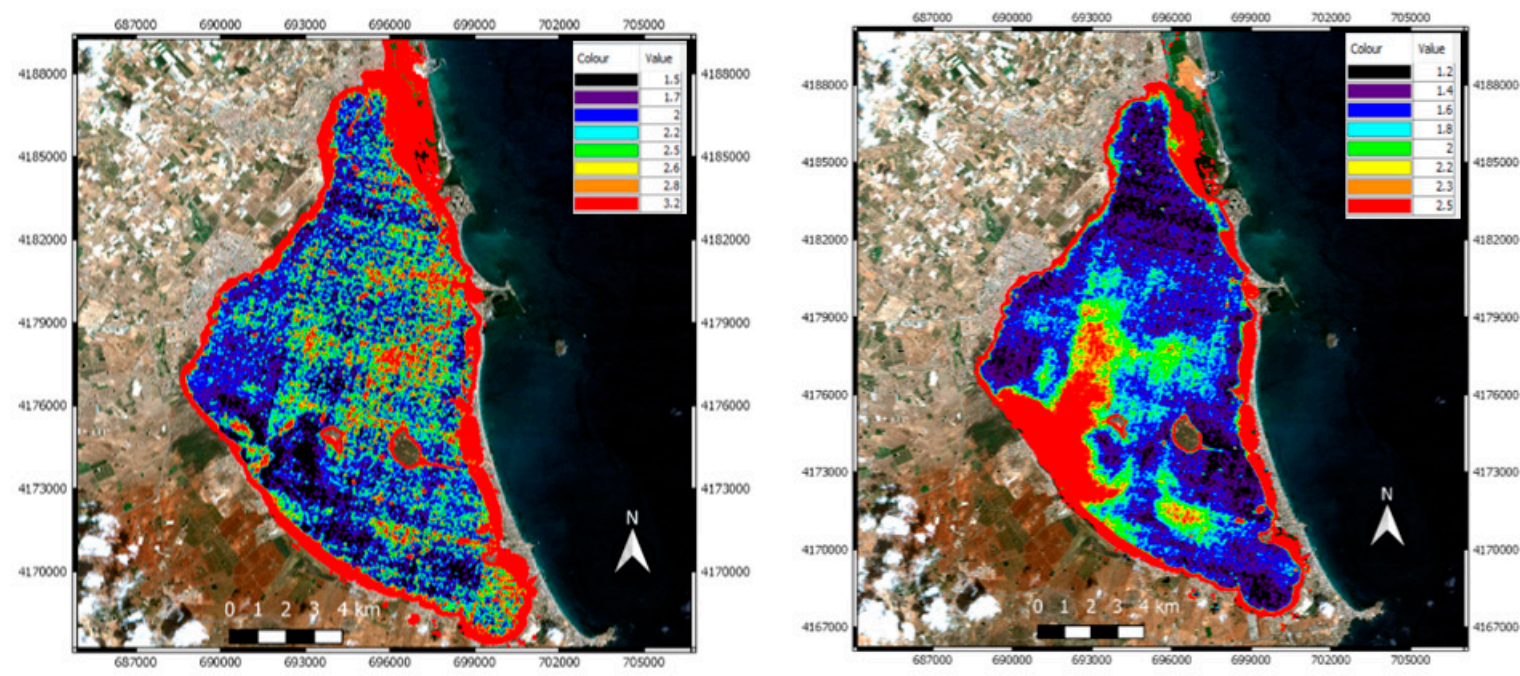

Figure 5. Thematic maps of Mar Menor, August 14, 2019. [Chl- $a]\left(\mathrm{mg} / \mathrm{m}^{3}\right)$ map obtained with equation 1 (on the left) and turbidity (NTU) map obtained with equation 3 (on the right). Mapa del Mar Menor del 14 de agosto, 2019. Mapa de [Chl-a] (mg/m³) obtenido con la ecuación 1(a la izquierda) y el mapa de turbidez (NTU) obtenido con la ecuación 3 (a la derecha).

It makes sense that the best correlations are obtained with the bands $783 \mathrm{~nm}$ and $865 \mathrm{~nm}$ since with small amounts of suspended particles, the strong water absorption in this spectral region overcomes and makes the reflectance near to zero, while the band $705 \mathrm{~nm}$ is mainly related to phytoplankton backscattering that is found, increasing turbidity within the suspended solids set. The presence of the $490 \mathrm{~nm}$ blue band is also observed in all relationships, since its reflectance decreases with the increase of suspended particles.

The best correlation to retrieval turbidity has been obtained with a two band model tested in this study, R705*R705/R490. The good coefficient of correlation and the low NRMSE $=10.9 \%$, show that the algorithm used delivers very good matching results for the studied water body.

Regarding studies carried out specifically at Mar Menor, using Landsat satellite images Erena et al. (2019) obtained the best correlation index combining green and red bands

$$
\frac{R(\text { green })-R(\text { red })}{R(\text { green })+R(\text { red })}
$$

with $\mathrm{R}^{2}=0.775$, but this model tested in this study obtained $\mathrm{R}^{2}=0.542$.
The wavelength range between 700 to $900 \mathrm{~nm}$ can be used to get information about a wide range of turbidity levels, because it responds to distinct different reflectance values corresponding to different turbidity values, exhibiting an increase with increasing turbidity (Bhargava \& Mariam, 1990). An example is the study by Al-fahdawi et al. (2015) for monitoring of water quality in Lake Habbaniyah (Iraq). It was found that Landsat 8 satellite near infrared band (NIR, 850-880 nm) was the highest correlation with turbidity (5-51 NTU) during winter season with $\mathrm{R}^{2}=0.790$. This band is present, in our case, in 2 of the 5 best indices for turbidity estimating. This particular band (859 nm) was studied by Dogliotti et al. (2015) in coastal waters, concluding that it could be used to retrieve turbidity from water reflectance for values since 15 up to $1000 \mathrm{NTU}$, while for values under $15 \mathrm{NTU}$ it is better to use the band $645 \mathrm{~nm}$, according to Petus et al. (2010) showing that MODIS band $859 \mathrm{~nm}$ is not sensitive enough to detect turbidity variations between 0.01 and 10 FNU. For this reason, in our case Mar Menor limnological characteristics have a leaving water reflectance spectra where the red-edge bands are best correlated with this turbidity range. Furthermore, the band $490 \mathrm{~nm}$ is also used in our best 
band combinations. This is related with the diffuse attenuation coefficient of seawater at $490 \mathrm{~nm}$ (Mueller, 2000) and so is used by Delegido et al. (2019) to estimate Secchi disc depth (SD), which is directly related with the turbidity.

\section{Thematic maps}

During September 2019 there were heavy torrential rains in the region near Mar Menor. In order to analyze whether the methodology developed in this work is capable of observing both the spatial distribution of water quality and the modification of studied variables after these torrential rains, maps of $[\mathrm{Chl}-a]$ and turbidity were produced before and after rains. The maps generated from Sentinel-2 image of August 14, 2019, with equation (1) for [Chl-a] and equation (3) for turbidity are shown in figure 5, where shoreline results are affected by bottom reflectance. That month had an average rainfall of $14 \mathrm{~L} / \mathrm{m}^{2}$ at Murcia region (AEMET, 2020). The [Chl- $a$ ] map shows concentrations ranging from 1.2 to $4 \mathrm{mg} / \mathrm{m}^{3}$ and a dark blue zone can be seen in the south-west with low $[\mathrm{Chl}-a$ ] values, corresponding to the water entry through Miedo and Miranda brooks (Fig. 6), which are entry points for water from agriculture and rainfall. The turbidity map shows high turbidity values in this area, which may indicate that incoming water is rich in suspension particles but not in phytoplankton. Near the shores of the lagoon and the edges of the two islands located at the center, the maximum [Chl- $a$ ] and turbidity concentrations are found (see red color in the maps), partly due to shallow depth of the lagoon near the shore sides. On the other hand, the turbidity map shows a well-distinguished red area close to the Albujón, Miranda, Miedo, Matildes and Beal brooks (Fig. 6) with turbidity values higher than 2.5 NTU or more, whose sediment, advancing into the lagoon, forms a turbidity pen.

To show the map values distribution of figure 5 , histograms (number of pixels of each value on the map) for both images have been represented in figure 7 . The histogram on the left shows [Chl- $a$ ] concentrations between 0 and $5 \mathrm{mg} / \mathrm{m}^{3}$ predominating a mean of $4.2 \mathrm{mg} / \mathrm{m}^{3}$ and standard deviation (sigma) of $5.3 \mathrm{mg} / \mathrm{m}^{3}$. Values between 1 and 3 NTU are predominant in the turbidity map,

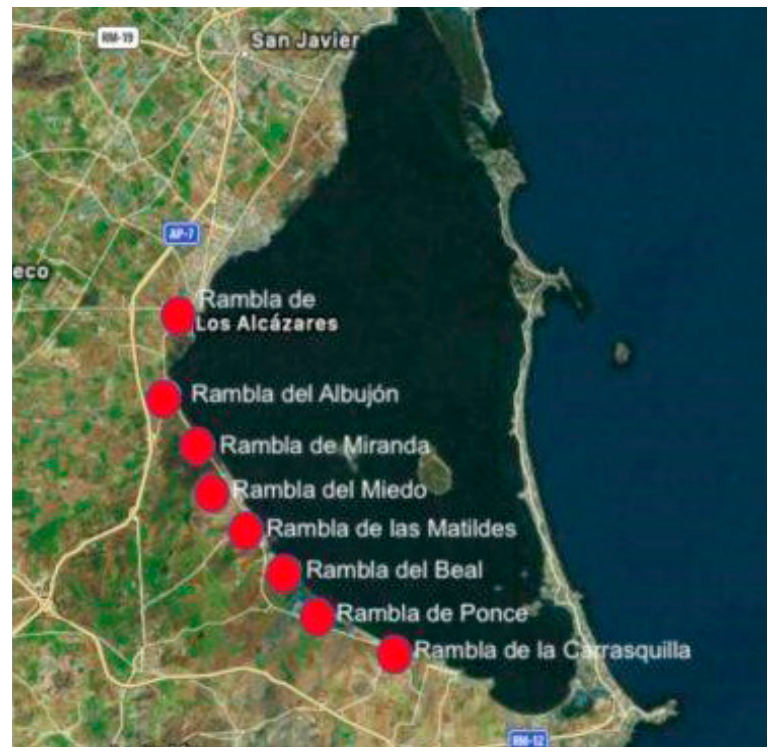

Figure 6. Location of brook inflows into Mar Menor (Sanchez, 2019). Localización de las ramblas en el Mar Menor.

as can be seen in the right histogram of figure 7, with a mean across the lagoon of 2.2 NTU and a sigma of $1.5 \mathrm{NTU}$.

[Chl-a] and turbidity maps from Sentinel-2 image corresponding to September 18, 2019 are shown in figure 8 . This was the first date with a Sentinel-2 acquisition after the torrential rains that occurred on September 11 to 15 in Murcia region, with a precipitation greater than $200 \mathrm{~L} / \mathrm{m}^{2}$ (AEMET, 2020), whose consequences can be seen at Mar Menor. A color map (RGB composition) showing the presence of clouds is in figure 8A. In order to perform a statistical analysis, it is necessary to remove the clouds by means of a cloud mask developed using the band 10 of Sentinel-2, as shown in figure $8 \mathrm{~B}$.

By comparing the [Chl- $a$ ] map (Fig. 8C) after the torrential rains with the [Chl- $a$ ] concentration map before the rains (Fig. 5, August 2019), it can be observed that [Chl- $a$ ] has increased considerably from an average of $4.2 \mathrm{mg} / \mathrm{m}^{3}$ before the rain event to values between 20 and $32 \mathrm{mg} / \mathrm{m}^{3}$ (Fig. 9) with an average of $22.7 \mathrm{mg} / \mathrm{m}^{3}$ and a sigma of $6.6 \mathrm{mg} / \mathrm{m}^{3}$ after this event.

Similarly, in figure 8D the Mar Menor turbidity map obtained with equation 3 is shown, ob- 

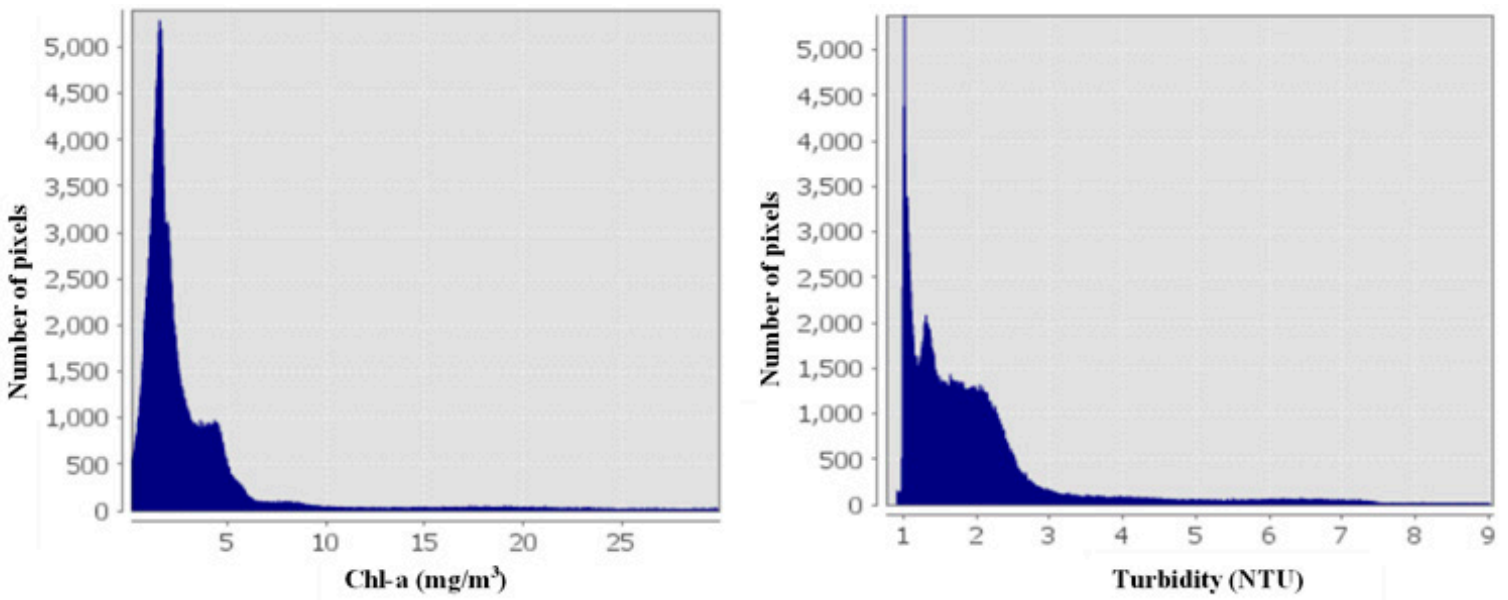

Figure 7. Histogram of [Chl-a] (left) and turbidity (right) corresponding to maps, August 14, 2019. Histograma de la [Chl-a] (izquierda) y la turbidez (derecha) de los mapas correspondientes al 14 de agosto de 2019.
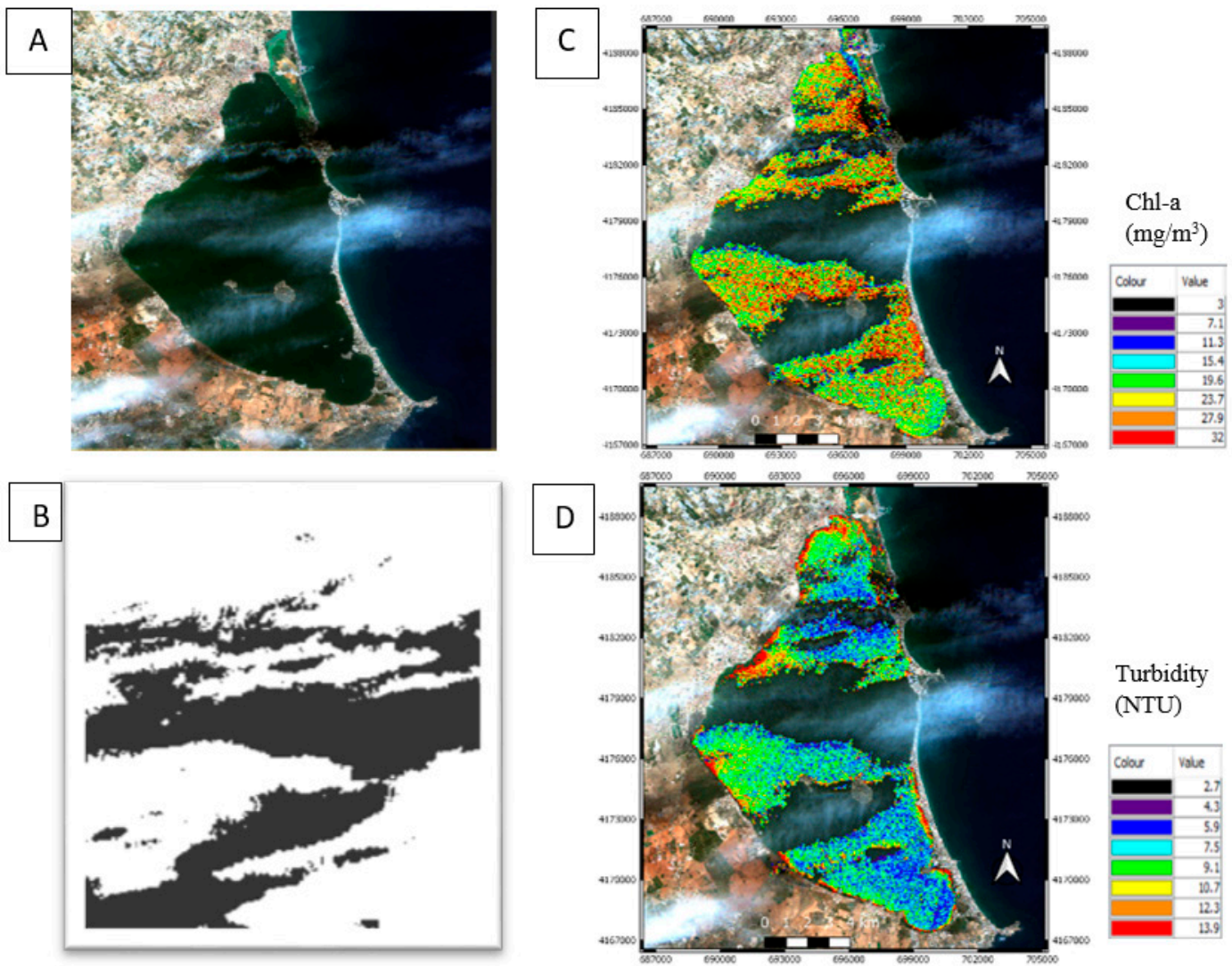

Figure 8. RGB and [Chl- $a$ ] maps obtained with equation 1 (above). Cloud mask and turbidity map obtained with equation 3 (below). Date at September 18, 2019. Mapas de RGB y [Chl-a] obtenidos con la ecuación 1(arriba). Mapas de la máscara de nubes y turbidez obtenidos con la ecuación 3 (abajo). Fecha del 18 de septiembre de 2019. 

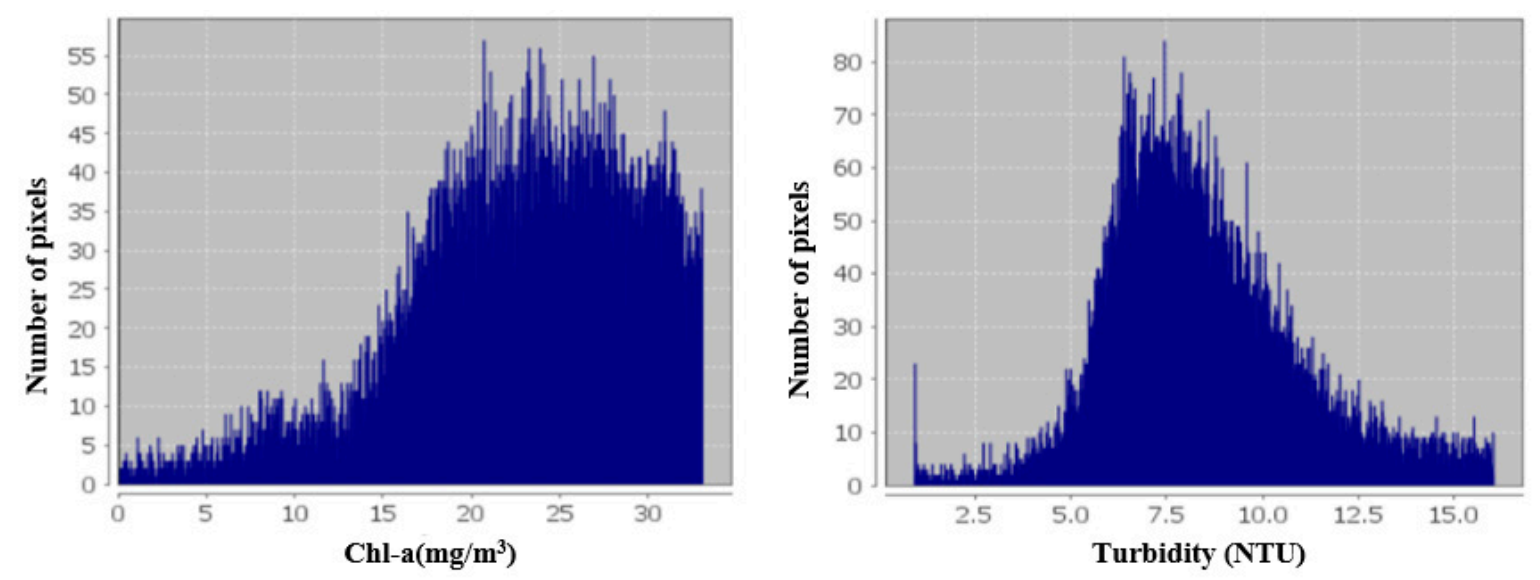

Figure 9. Histogram of [Chl-a] (left) and turbidity (right) corresponding to maps, September 18, 2019. Histograma de los mapas de [Chl-a] (izquierda) y turbidez (derecho) correspondientes al 18 de septiembre de 2019.

serving that the turbidity also increased after the torrential rains, changing from an average of 2.2 NTU before the rains to a mean turbidity of 8.4 NTU and a sigma of $2.5 \mathrm{NTU}$ after this event. It was observed that at central-west part of the lagoon, corresponding to the brook's inflow of Albujón and Miranda (Fig. 6), there is a patch with values around 9.1 NTU (in green on the map), as a consequence of the dragging of sediments and residues caused by heavy rains (Velasco et al., 2006). This phenomenon also occurs in a large part of the western shores, where there is high turbidity, appreciating how it decreases when the water flow from the brooks advances into the lagoon (sediment plumes formation).

\section{CONCLUSIONS}

In this work, Sentinel-2 reflectances were subjected to a regression analysis against Mar Menor database of in situ measurements, to obtain a set of [Chl- $a$ ] and turbidity models.

The automatic product to estimate [Chl- $a]$, generated by SNAP with the C2X processor has been validated with field data and we have found that it obtains good results with an RMSE $=3.9 \mathrm{mg} / \mathrm{m}^{3}$ and NRMSE $=10.48 \%$. Moreover, calibration models with field [Chl- $a$ ] data show that the best spectral index is $(\mathrm{R} 560+\mathrm{R} 705) /(\mathrm{R} 560+\mathrm{R} 665)$ with linear fit and $\mathrm{R}^{2}=0.82, \mathrm{RMSE}=2.6 \mathrm{mg} / \mathrm{m}^{3}$ and NRMSE $=9.06 \%$, which slightly improves the results of the automatic product.

On the other hand, for turbidity with the $\mathrm{R} 705 * \mathrm{R} 705 / \mathrm{R} 490$ combination, was obtained the best correlation, with a linear model of $\mathrm{R}^{2}=0.73$ and $\mathrm{RMSE}=1.5 \mathrm{NTU}$ and NRMSE $=10.9 \%$.

Both relationships allow us to generate thematic maps in which the spatial distribution of both variables are represented and serves to identify the impact of the water entering into the lagoon, such as the increase in [Chl- $a$ ] and turbidity after torrential rains.

These results indicated the capacity of this method to monitor Mar Menor water quality variables [Chl- $a$ ] and turbidity. It could be used to carry out spatial and temporal monitoring of the lagoon as well as an early warning system to prevent and avoid environmental disasters. It is also important and necessary to take in situ data to increase the database, carry out periodic model checks, and recalibrate the model in the event of changes in the trophic state.

\section{ACKNOWLEDGMENTS}

The authors wish to express their gratitude to researchers and field and laboratory technicians of IMIDA (Murcian Institute for Agricultural and Food Research and Development) for their work, permitting the generation of the valuable 
Mar Menor database of water quality and for sharing their data.

\section{REFERENCES}

AEMET. (2020). Agencia Estatal de Meteorología. Available on http://www.aemet.es

Al-fahdawi, A.A.H., Rabee, A.M. \& Al-hirmizy, S.M. (2015). Water quality monitoring of al-habbaniyah lake using remote sensing and in situ measurements. Environmental monitoring and assessment, 187, 367. DOI: 10.1007/ s10661-015-4607-2

Álvarez, J., González, M.N., Conesa, H.M., Tercero, M.D.C., Párraga, I.M., María, A. \& Jiménez, F.J. (2016). Capítulo 11: Eutrofización y contaminación por residuos mineros en humedales del Mar Menor, comprendiendo los procesos biogeoquímicos para plantear posibles actuaciones de manejo. En Mar Menor: una laguna singular y sensible. Evaluación cientifica de su estado (pp.251-270). Madrid: Instituto Español de Oceanografía, Ministerio de Economía y Competitividad.

Bhargava, D.S. \& Mariam, D.W. (1990). Spectral reflectance relationships to turbidity generated by different clay materials. Photogrammetric Engineering and Remote Sensing, 56(2), 225-229.

Benedicto, J., Marín-Guirao, L. \& Pérez, J. (2009). Capítulo VI: Contaminación por metales y compuestos organoestánnicos en el Mar Menor. En El Mar Menor. Estado actual del conocimiento cientifico (pp. 201-238). Murcia: Fundación para la protección y conservación del Mar Menor y Fundación Instituto Euromediterráneo del Agua.

Bonilla, S. \& Conde, D. (2000). El fitoplancton como descriptor sensible de cambios ambientales en las lagunas costeras de la Reserva Bañados del Este. Seminario-Taller sobre monitoreo ambiental, 31 .

Brockmann, C., Doerffer, R., Peters, M., Kerstin, S., Embacher, S., \& Ruescas, A. (2016). Evolution of the C2RCC neural network for Sentinel 2 and 3 for the retrieval of ocean colour products in normal and extreme optically complex waters. ESASP, 740, 54.

Caballero, I., Steinmetz, F. \& Navarro, G. (2018).
Evaluation of the first year of operational Sentinel-2A data for retrieval of suspended solids in medium-to high-turbidity waters. Remote Sensing, 10(7), 982. DOI: 10.3390/ rs10070982

Cairo, C., Barbosa, C., Lobo, F., Novo, E., Carlos, F., Maciel, D., ....Curtarelli, V. (2019). Hybrid Chlorophyll- $a$ Algorithm for Assessing Trophic States of a Tropical Brazilian Reservoir Based on MSI/Sentinel-2 Data. Remote Sensing, 12, 40. DOI: 10.3390/rs12010040

Calvo, E. (2020). La exposición a metales pesados de la minería acelera el colapso del Mar Menor. Eldiario.es. Recovered in January of 2020, available on: https:/www.eldiario.es/murcia/medio_ ambiente/exposicion-metales-pesados-MarMenor_0_999850296.html

Campillo, J. A., Albentosa, M., Valdés, N.J., Moreno-González, R., \& León, V. (2013). Impact assessment of agricultural inputs into a Mediterranean coastal lagoon (Mar Menor, SE Spain) on transplanted clams (Ruditapes decussatus) by biochemical and physiological responses. Aquatic Toxicology, 142, 365-379. DOI: 10.1016/j.aquatox.2013.09.012

Candiani, G., Floricioiu, D., Giardino, C., \& Rott, H. (2005). Monitoring water quality of the perialpine Italian Lake Garda through multitemporal MERIS data. In Proceedings of the MERIS (A)ATSR Workshop, 26-30 September 2005, Frascati, Italy.

Chen, J., Zhu, W., Tian, Y.Q, Yu, Q., Zheng, Y., \& Huang, L. (2017). Remote estimation of colored dissolved organic matter and chlorophyll- $a$ in Lake Huron using Sentinel-2 measurements. Journal of Applied Remote Sensing, 11(3), 036007. DOI: 10.1117/1.JRS.11.036007

Dall'olmo, G., Gitelson, A. \& Rundquist, D. (2003). Towards a unified approach for remote estimation of chlorophyll- $a$ in both terrestrial vegetation and turbid productive waters. Geophysical Research Letters, 30(18). DOI: 10.1029/2003GL018065

De la Peña, A. (2020). La gran sopa verde está aquí y amenaza a las especies del Mar Menor. La Opinión de Murcia. Recovered in January 2020, available on https://www.laopiniondemurcia. es/comunidad/2020/02/26/gran-sopa-verdeamenaza-especies/1094462.html 
Delegido, J., Tenjo, C., Ruiz-verdú, A., Peña, R. \& Moreno, J. (2014). Modelo empírico para la determinación de clorofila-a en aguas continentales a partir de los futuros Sentinel-2 y 3. Validación con imágenes HICO. Revista de Teledetección, (41), 37-47. DOI: 10.4995/ raet.2014.2295

Delegido, J., Urrego, P., Vicente, E., Sòria-perpinyà, X., Soria, J.M., Pereira-Sandoval, M., Ruiz-Verdú, A., Peña, R.\& Moreno, J. (2019). Turbidity and Secchi disc depth with Sentinel-2 in different trophic status reservoirs at the Comunidad Valenciana. Revista de Teledetección, (54), 15-24.

Dogliotti, A.I., Ruddick, G.K., Nechad, B., Doxaran, D., \& Knaeps, E. (2015). A single algorithm to retrieve turbidity from remotely-sensed data in all coastal and estuarine waters. Remote sensing of environment, 156, 157-168.

Doxaran, D., Froidefond, J.M., Lavender, S. \& Castaing, P. (2002). Spectral signature of highly turbid waters: application with SPOT data to quantify suspended particulate matter concentrations. Remote Sensing of Environment, 81, 149-161. DOI: 10.1016/S0034-4257 (01)00341-8

Doxaran, D., Froidefond, J.M., Castaing, P. \& Babin, M. (2009). Dynamics of the turbidity maximum zone in a macrotidal estuary (the Gironde, France): observations from field and MODIS satellite data. Estuarine, Coastal and Shelf Science, 81, 321-332. DOI: 10.1016/j. ecss.2008.11.013

Drusch, M., Del Bello, U., Carlier, S., Colin, O., Fernandez, V., Gascon, F., \& Meygret, A. (2012). Sentinel-2: ESA's optical high-resolution mission for GMES operational services. Remote sensing of Environment, 120, 25-36. DOI: 10.1109/IGARSS.2007.4423394

Elosegi, A. \& Sabater, S. (2009). Concepto y técnicas en ecología fluvial. Bilbao, España: Rubes Editorial. Ed. Fundación BBVA.

Erena, M., Domínguez, J.A., Soria, J., Aguado-Giménez, F., García-pintado, J., Melendreras, R., Atenza, J. \& Lopez, J. (2017). Análisis multisensor de la variabilidad espacio temporal de diversos parámetros biofísicos en el Mar Menor. XVII Congreso de la Asociación Es- pañola de Teledetección, Murcia, 2017.

Erena, M., Domínguez, J.A., Aguado-giménez, F., Soria, J. \& García-Galiano, S. (2019). Monitoring Coastal Lagoon Water Quality through Remote Sensing: The Mar Menor as a Case Study. Water, 11(7), 1468. DOI: 10.3390/ w11071468

Erena, M. (2020). La exposición a metales pesados de la minería acelera el colapso del Mar Menor. Eldiario.es. Recovered in January 2020, available on: https://www.eldiario.es/murcia/medio ambiente/exposicion-metales-pesadosMar-Menor 0 999850296.html

ESA. (2020). Sentinel-2, Missions. Recovered in January 2020, available on: https://sentinel. esa.int/web/sentinel/missions/sentinel-2

FAO. (2015). Organización de las naciones unidas para la alimentación y la agricultura. Los lagos y ríos son esenciales para el sustento de millones de personas. Roma, Italia: Noticias FAO. Recovered in February 2020, available on: http://www.fao.org/news/ story/es/item/276124/icode

FAO. (2020). Ecosistemas acuáticos continentales. Departamento de pesca y agricultura. Recovered in January 2020, available on: http:// www.fao.org/fishery/ecosystems/inland/es

Flink, P., Lindell, T. \& Östlund, C. 2001. Statistical analysis of hyperspectral data from two Swedish lakes. Science of the Total Environment, 268, 155-169. DOI: 10.1016/S0048-9697 (00)00686-0

Floricioiu, D., Rott, H., Rott, E., Dokulil, M. \& Defrancesco, C. (2003). Retrieval of limnological parameters of perialpine lakes by means of MERIS data. In Proceedings of the 2004 Envisat \& ERS Symposium (ESA SP572), 6-10 September 2004, Salzberg, Austria, pp. 1-5 (Paris: ESA).

Garcia-Oliva, M., Perez-Ruzafa, A., Umgiesser, G., Mckiver, W., Ghezzo, M., De Pascalis, F. \& Marcos, C. (2018). Assessing the hydrodynamic response of the Mar Menor lagoon to dredging inlets interventions through numerical modelling. Water, 10, 959. DOI: 10.3390/ w10070959.

Giardino, C., Candiani, G. \& Zilioli, E. (2005). Detecting chlorophyll- $a$ in Lake Garda using TOA MERIS radiances. Photogrammetric 
Engineering and Remote Sensing, 71, 10451051. DOI: 10.14358/PERS.71.9.1045

Gitelson, A., Garbuzov, G., Szilagyi, F., Mittenzwey, K., Karnieli, A. \& Kaiser, A. (1993). Quantitative remote sensing methods for real-time monitoring of inland waters quality. International Journal of Remote Sensing, 14, 1269-1295. DOI: 10.1080/ 01431169308953956

Gitelson, A.A., Gurlin, D., Moses, W.J. \& Barrow, T. (2009). A bio-optical algorithm for the remote estimation of the chlorophyll- $a$ concentration in case 2 waters. Environmental Research Letters, 4, 045003.

Han, B., Loisel, H., Vantrepotte, V., Mériaux, X., Bryère, P., Ouillon, S. \& Zhu, J. (2016). Development of a semi-analytical algorithm for the retrieval of suspended particulate matter from remote sensing over clear to very turbid waters. Remote Sensing, 8(3), 211. DOI: 10.3390/rs8030211

Härmä, P., Vepsalainen, J., Hannonen, T., Pyhalahti, T., Kamari, J., Kallio, K., ....Koponen, S. (2001). Detection of water quality using simulated satellite data and semi-empirical algorithms in Finland. Science of the Total Environment, 268, 107-121. DOI: 10.1016/S00489697(00)00688-4

Hieronymi, M., Krasemann, H., Müller, D., Brockmann, C., Ruescas, A., Stelzer, K., .... Regner, P. (2016). Ocean Colour Remote Sensing of Extreme Case-2 Waters. In Proceedings of Living Planet Symposium (Prague: ESA SP-740).

Hou, X., Feng, L., Chen, X., Sun, D. \& Shi, K. (2017). Fifteen-year monitoring of the turbidity dynamics in large lakes and reservoirs in the middle and lower basin of the Yangtze River, China. Remote Sensing of Environment, 190, 107-121. DOI: 10.1016/j.rse.2016.12.006

Jutz, S. \& Milagro-Pérez, M.P. (2020). Copernicus: the European Earth Observation programme. Revista de Teledetección, 56, V-IX. DOI: 10.4995/raet.2020.14346

Kallio, K., Kutser, T., Hannonen, T., Koponen, S., Pulliainen, J., Vepsalainen, J. \& Pyhalahti, T. (2001). Retrieval of water quality from airborne imaging spectrometry of various lake types in different seasons. Science of the To- tal Environment, 268, 59-77. DOI: 10.1016/ S0048-9697(00)00685-9

Koponen, S., Pulliainen, J., Kallio, K. \& Hallikainen, M. (2002). Lake water quality classification with airborne hyperspectral spectrometer and simulated MERIS data. Remote Sensing of Environment, 79, 51-59. DOI: 10.1016/S00344257(01)00238-3

Koponen, S., Attila, J., Pulliainen, J., Kallio, K., Pyhalahti, T., Lindfors, A., .... Hallikainen, M. (2007). A case study of airborne and satellite remote sensing of a spring bloom event in the Gulf of Finland. Continental Shelf Research, 27, 228-244. DOI: 10.1016/j.csr.2006.10.006

Kutser, T. (2012). The possibility of using the landsat image archive for monitoring long time trends in coloured dissolved organic matter concentration in lake waters. Remote Sensing of Environment, 123, 334-338. DOI: 10.1016/j.rse.2012.04.004

Lathrop, R.G. \& Lillesand, T.M. (1989). Monitoring water quality and river plume transport in Green Bay, Lake Michigan with SPOT-1 imagery. Photogrammetric Engineering and Remote Sensing, 55, 349-354.

Lins, R.C., Martinez, J.M., Motta Marques, D.D., Cirilo, J.A., Fragoso, C.R. (2017). Assessment of chlorophyll- $a$ remote sensing algorithms in a productive tropical estuarine-lagoon system. Remote Sensing, 9(6), 516.

Marín-Guirao, L., Cesar, A., Marín, A. \& Vita, R. (2005). Assessment of sediment metal contamination in the Mar Menor coastal lagoon (SE Spain): Metal distribution, toxicity, bioaccumulation and benthic community structure. Ciencias Marinas, 31(2), 413-428.

Matthews, M. (2011). A current review of empirical procedures of remote sensing in inland and near-coastal transitional waters. International Journal of Remote Sensing, 32(21), 68556899. DOI: 10.1080/01431161.2010.512947

MITECO.(2020). Ministerio para la transición ecológica y el reto demográfico. Copernicus. Recovered in May 2020, available on: https://www.miteco.gob.es/es/calidad-yevaluacion-ambiental/temas/agencia-europeamedio-ambiente-informacion-ambiental/ copernicus/default.aspx

Moses, W.J., Gitelson, A.A., Berdnikov, S. \& 
Povazhnyy, V. (2009). Estimation of chlorophyll- $a$ concentration in case II waters using MODIS and MERIS data - successes and challenges. Environmental Research Letters, 4, 045005.

Mueller, J. L. (2000). SeaWIFS algorithm for the diffuse attenuation coefficient, K (490), using water-leaving radiances at 490 and $555 \mathrm{~nm}$. SeaWiFS postlaunch calibration and validation analyses, 3, 24-27.

Müller, D., Krasemann, H., Brewin, R.J., Brockmann, C., Deschamps, P.Y. Doerffer, R., .... Swinton, J. (2015). The Ocean Colour Climate Change Initiative: I. A methodology for assessing atmospheric correction processors based on in-situ measurements. Remote Sensing of Environment, 162, 242-256.

Ogashawara, I., Mishra, D.R. \& Gitelson, A.A. (2017). Remote sensing of inland waters: background and current state-of-the-art. In Bio-optical modeling and remote sensing of inland waters (pp. 1-24). Elsevier. DOI: 10.1016/B978-0-12-804644-9.00001-X

Pereira-Sandoval, M., Ruescas, A., Urrego, P., Ruiz-Verdú, A., Delegido, J., Tenjo, C., .... Moreno, J. (2019). Evaluation of atmospheric correction algorithms over Spanish inland waters for sentinel-2 multi spectral imagery data. Remote Sensing, 11(12), 1469.

Pérez-Ruzafa, A., Fernández, A., Marcos, C., Gilabert, J. Quispe, J.I. \& García-Charton, J.A. (2005). Spatial and temporal variations of hydrological conditions, nutrients and chlorophyll $a$ in a Mediterranean coastal lagoon (Mar Menor, Spain). Hydrobiologia, 550(1), 11-27. DOI: $10.1007 / \mathrm{s} 10750-005-4356-2$

Perez-Ruzafa, A., C. Marcos, C. \& Perez-Ruzafa, I.M. (2011). Mediterranean coastal lagoons in an ecosystem and aquatic resources management context. Physics and Chemistry of the Earth, 36, 160-166. DOI: 10.1016/j.pce. 2010.04.013

Perez-Ruzafa, A., Marcos, C., Perez-Ruzafa, I.M. \& Perez-Marcos, M. (2013). Are coastal lagoons physically or biologically controlled ecosystems? Revisiting r vs. K strategies in coastal lagoons and estuaries. Estuarine, Coastal and Shelf Science, 132, 17-33. DOI: 10.1016/ j.ecss.2012.04.011
Pérez-Ruzafa, A., Campillo, S., Fernández-Palacios, J.M., García-Lacunza, A., García-OLIVA, M., Ibañez, H. \& Sala-Mirete, A. (2019). Long-Term Dynamic in Nutrients, Chlorophyll $a$, and Water Quality Parameters in a Coastal Lagoon During a Process of Eutrophication for Decades, a Sudden Break and a Relatively Rapid Recovery. Frontiers in Marine Science, 6(26), 1-23. DOI: 10.3389/fmars.2019.00026

Petus, C., Chust, G., Gohin, F., Doxaran, D., Froidefond, J.M. \& Sagarminaga, Y. (2010). Estimating turbidity and total suspended matter in the Adour River plume (South Bay of Biscay) using MODIS 250-m imagery. Continental Shelf Research, 30, 379-392. DOI: 10.1016/j.csr.2009.12.007

Sanchez, M.I., Lopez, F., Del Amor, F. \& Torrecillas, A. (1989). La evaporación y evapotranspiración en el Campo de Cartagena y Vega Media del Segura. Primeros resultados. Anales de Edafologia y Agrobiologia, 1239-1251.

Sanchez, P. (2019). Las últimas lluvias torrenciales de agosto contaminan todavía más el maltrecho Mar Menor. La crónica del Pajarito. Recovered in February 2020, available on: https://lacronicadelpajarito.com/region/lasultimas-lluvias-torrenciales-de-agostocontaminan-todavia-mas-el-maltrechomar-menor

Sebastiá-Frasquet, M. T., Aguilar-Maldonado, J.A., Santamaría-Del-Ángel, E. \& Estornell, J. (2019). Sentinel 2 Analysis of Turbidity Patterns in a Coastal Lagoon. Remote Sensing, 11(24), 2926. DOI: 10.3390/rs11242926

Soomets, T., Uudeberg, K., Jakovels, D., Brauns, A., Zagars, M. \& Kutser, T. (2020). Validation and Comparison of Water Quality Products in Baltic Lakes Using Sentinel-2 MSI and Sentinel-3 OLCI Data. Sensors, 20(3), 742. DOI: 10.3390/s20030742

Strömbeck, N., Candiani, G., Giardino, C. \& Zilioli, E. (2003). Water quality monitoring of Lake Garda using multi-temporal MERIS data. MERIS Users Workshop, Frascati, Italy, 10-13 November 2003, ESA SP-549.

Sòria-Perpinyà, X., Urrego, P., Pereira-Sandoval, M., Ruiz-Verdú, A., Peña, R., Soria, J.M., .... Moreno, J. (2019). Monitoring the ecological state of a hypertrophic lake (Albufera of 
València, Spain) using multitemporal Sentinel-2 images. Limnetica, 38 (1), 457-469. DOI: $10.23818 /$ limn.38.26

Warren, M. A., Simis, S.G., Martinez-Vicente, V., Poser, K., Bresciani, M., Alikas, K. \& Ansper, A. (2019). Assessment of atmospheric correction algorithms for the Sentinel-2A MultiSpectral Imager over coastal and inland waters. Remote sensing of environment, 225 , 267-289. DOI: 10.1016/j.rse.2019.03.018

Yuan, L., Yulong, G., Chunmei, C., Yibo, Z., Yaoduo, H., Zhong, X. \& Shun, B. (2019). Remote estimation of total suspended matter concentration in the Hangzhou Bay based on OLCI and its water color product applicability analysis. Haiyang Xuebao, 41(9), 156-169. 